\title{
CAN RETINOSCOPY BE USED TO SCREEN INFANTS FOR AMBLYOPIA? A LONGITUDINAL STUDY OF REFRACTION IN THE FIRST YEAR OF LIFE
}

\author{
B. HOPKISSON, P. ARNOLD, B. BILLINGHAM, M. McGARRIGLE, S. SHRIBMAN \\ Northampton
}

\begin{abstract}
SUMMARY
One hundred normal babies were refracted by two observers in a double-masked study within 24 hours of delivery and 30 minutes after instillation of $1 \%$ cyclopentolate. The procedure was repeated at 6 weeks, 3 months, 6 months and 1 year. At birth agreement between the two refractionists to within 1 dioptre spherical equivalent was $82 \%$, rising to $94 \%$ at 1 year. Astigmatism of greater than 1 dioptre increased from $10 \%$ at birth to $42 \%$ at 6 months but decreased to $15 \%$ at 1 year. Myopia was uncommon (4\%) but $80 \%$ of eyes were hypermetropic more than +2 dioptres and $25 \%$ more than +4 dioptres at birth, although these percentages decreased to $5 \%$ and $3 \%$ at 1 year. Anisometropia of more than 1 dioptre between the two eyes was uncommon but in the two cases where it persisted in the presence of high hypermetropia, reversible amblyopia was encountered in both cases.
\end{abstract}

The risk of developing amblyopia is greatly increased in infants with hypermetropia and anisometropia. ${ }^{1,2}$ Bilateral refractive errors may lead to bilateral amblyopia ${ }^{3}$ and meridional amblyopia may ensue when astigmatism is uncorrected in childhood. ${ }^{4}$

Approximately $6 \%$ of young infants have a significant refractive error and most are hypermetropic. ${ }^{5,6}$ Astigmatism is common in normal infants ${ }^{7-10}$ but the degree of astigmatism decreases ${ }^{8,9,11}$ and the axis of the astigmatism changes with age. ${ }^{10,12}$ Astigmatism rarely develops after the age of 1 year. ${ }^{12}$

Various techniques have been used to assess the refractive error in infants including retinoscopy (static and dynamic),${ }^{13}$ photorefraction, ${ }^{6,7}$ autorefraction, ${ }^{14,15}$ and visual evoked responses. ${ }^{16}$

In Northampton, orthoptists have been performing retinoscopy as a static procedure with accommodation relaxed under cyclopentolate cycloplegia for some years. ${ }^{17}$ It was decided to investigate retinoscopy at birth and during the first year of life to see whether amblyopia could be identified and treated earlier than ever before. ${ }^{18}$ The objectives were therefore threefold:

Correspondence to: Mr. B. Hopkisson, MA, FRCS, FCOphth, Eye Department, Northampton General Hospital, Northampton NN1 5BD, UK.

Eye (1992) 6, 607-609
1. To demonstrate the reliability of orthoptists' refractions on a very difficult group of children, the newborn and the very young.

2. To ascertain the normal refractive range of infants in the first year of life.

3. To determine the youngest age at which it would prove practical to screen by refraction.

\section{PATIENTS AND METHODS}

A sample of 100 newborn babies, as consecutive as possible, was obtained from the two maternity wards at Northampton District General Hospital beginning on 30 October 1989, all babies being examined within 24 hours of delivery on Monday to Friday mornings at 0800 hours. All the babies were full-term, normal deliveries of birth weight no less than $2.3 \mathrm{~kg}$.

Once consent had been obtained, $1 \%$ cyclopentolate drops were instilled into the baby's eyes and all the babies

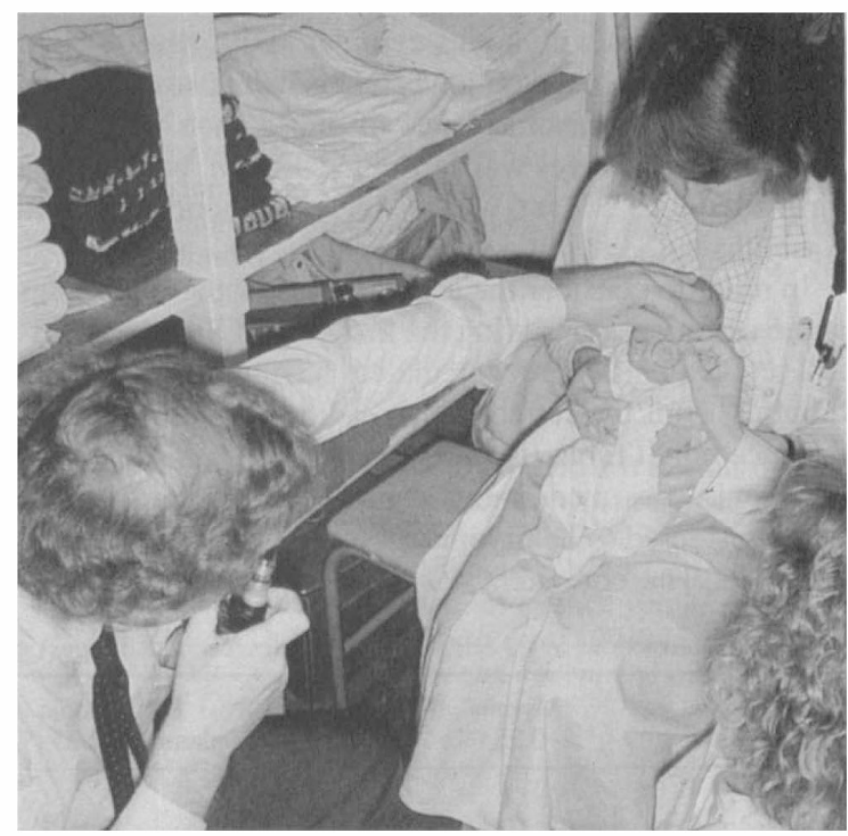

Fig. 1. Retinoscopy within 24 hours of birth. 
Table I. Summary of results

\begin{tabular}{lcccc}
\hline Age & Attendance & Agreement of two refractionists (\%) & Astigmatism (\%) & Anisometropia (\%) \\
\hline Birth & 100 & 82 & 10 & 9 \\
6 weeks & 56 & 86 & 11 & 3.5 \\
3 months & 67 & 77 & 17 & 4.5 \\
6 months & 55 & 94 & 42 & 1.8 \\
1 year & 53 & 94 & 15 & 3.8 \\
\hline
\end{tabular}

were refracted 30 minutes later (Fig. 1). Fourteen mothers declined our offer of examination of their babies and 100 had been examined by 28 November 1989 .

Retinoscopy was recorded by the first refractionist (BH) unseen by the second refractionist (PA or $\mathrm{BB}$ ), an orthoptist, who repeated the process and made a separate record of her retinoscopy. All retinoscopy was performed at $2 / 3$ metre using individual lenses held by the refractionist who attempted to attract the baby's attention to the retinoscopy light. All refractions were deduced by subtracting 1.5 dioptres from retinoscopy readings for working distance only; nothing was subtracted for cycloplegia. The process was repeated at 6 weeks, 3 months, 6 months and 1 year.

\section{RESULTS}

One hundred babies were refracted at birth (Table I), 56 attended at 6 weeks, 67 at 3 months, 55 at 6 months, and 53 at 1 year. Forty-four attended all examinations. The largest drop-out was from birth to 6 weeks, after which the numbers remained fairly constant. Agreement between the two refractionists to within 1 dioptre spherical equivalent was good. At birth it was $82 \%$, increasing to $94 \%$ at 6 months and 1 year. Astigmatism, defined as a difference between the two meridia of 1 dioptre or more, was found in $10 \%$ at birth but this rose to a maximum of $42 \%$ at 6 months, falling back again to $15 \%$ at 1 year. It was found that astigmatism with a plus cylinder at $90^{\circ}$ was twice as common as combined oblique and horizontal astigmatism at 6 months. Anisometropia of more than 1 dioptre between the two eyes was fairly uncommon, being $9 \%$ at birth but only $3.5 \%$ at 6 weeks, $4.5 \%$ at 3 months, $1.8 \%$ at 6 months and $3.8 \%$ at a year.

In order to consider the actual values of the refractions at the various stages during the first year of life, the spherical equivalents were calculated having deducted 1.5 dioptres from the retinoscopy readings for the working distance only (Table II).

Myopia was uncommon; at birth only $1 \%$ of the eyes was considered to be myopic, at 6 weeks $10 \%$ and thereafter $4 \%$. The consistent $4 \%$ were actually two infants, each with two myopic eyes of -1 sphere. Emmetropia, plano to +2.25 , increased from $18 \%$ at birth, through $43 \%$ at 6 weeks, $57 \%$ at 3 months and $75 \%$ at 6 months, to $88 \%$ at 1 year. Mild hypermetropia, +2.50 to +4.0 , decreased from $56 \%$ at birth to only $5 \%$ at a year. High hypermetropia, greater than +4.0 refraction, decreased from $25 \%$ of eyes at birth to $3 \%$ at 1 year.

Regardless of whether the high hypermetropia is studied as a percentage of eyes or a percentage of patients, the results are very similar (Table III). In terms of percentage of patients with refraction greater than +4 in any meridian, there were $40 \%$ at birth falling to $6 \%$ at a year. The percentage of patients with retinoscopy greater than +4 spherical equivalent was $35 \%$ at birth, again falling to $6 \%$ at 1 year. As a percentage of eyes, there are $25 \%$, reducing to $3 \%$ at a year. High hypermetropia decreases markedly from birth to 1 year, whichever calculation is used.

\section{DISCUSSION}

It is difficult to draw absolute conclusions from such a necessarily small study. It is clear, however, that orthoptists are able consistently to refract this difficult group of children, especially after the child reaches 6 months of age. It is also clear that, at birth, $80 \%$ of eyes are long sighted greater than +2.0 and $25 \%$ of eyes $(35-40 \%$ of patients) are hypermetropic greater than +4.0 dioptres. We feel confident that the vast majority of these hypermetropic eyes become more emmetropic by the age of 1 year, when $92 \%$ of eyes have refractions between -1.0 and +2.0 dioptres.

High hypermetropia combined with anisometropia causes concern and can lead to amblyopia. In our series the only two children with this combination were found to be amblyopic on Vernier strip testing, ${ }^{19}$ one at 12 months of age and the other at 22 months of age. The amblyopia was treated with appropriate spectacle correction and after 2 months of spectacle wear with no occlusion the amblyopia disappeared.

Astigmatism in infants is common: $42 \%$ of the children were astigmatic more than 1 dioptre at 6 months but only $15 \%$ remained so at 1 year. Of the infants astigmatic at

Table II. Refractions in spherical equivalents (percentage of eyes)

\begin{tabular}{lcccc}
\hline Age & $\begin{array}{c}\text { Myopia } \\
>-0.25(\%)\end{array}$ & $\begin{array}{c}\text { Emmetropia } \\
\text { plano to }+2.25(\%)\end{array}$ & $\begin{array}{c}\text { Mild hypermetropia } \\
+2.5 \text { to }+4.0(\%)\end{array}$ \\
\hline Births & 1 & 18 & 56 & 25 \\
6 weeks & 10 & 43 & 36 & 30 \\
3 months & 4 & 57 & 9 & 15 \\
6 months & 4 & 85 & 5 & 5 \\
1 year & 4 & 88 & 3 & 5 \\
\hline
\end{tabular}


Table III. Refraction greater than +4 dioptres

\begin{tabular}{|c|c|c|c|c|c|c|}
\hline \multirow{3}{*}{$\begin{array}{l}\text { Age } \\
\text { Birth }\end{array}$} & \multicolumn{4}{|c|}{$\%$ patients } & \multirow{2}{*}{\multicolumn{2}{|c|}{$\begin{array}{c}\% \text { eyes } \\
\begin{array}{c}\text { in spherical } \\
\text { equivalents }\end{array}\end{array}$}} \\
\hline & \multicolumn{2}{|c|}{$\begin{array}{l}\text { in any } \\
\text { meridian }\end{array}$} & \multicolumn{2}{|c|}{$\begin{array}{l}\text { in spherical } \\
\text { equivalents }\end{array}$} & & \\
\hline & 40 & $\left(\begin{array}{l}38 \\
94\end{array}\right)$ & 35 & $\left(\begin{array}{l}33 \\
94\end{array}\right)$ & 25 & $\left(\begin{array}{r}46 \\
188\end{array}\right)$ \\
\hline 6 weeks & 12.5 & $\left(\begin{array}{r}7 \\
56\end{array}\right)$ & 11 & $\left(\begin{array}{r}6 \\
56\end{array}\right)$ & 11 & $\left(\begin{array}{r}12 \\
112\end{array}\right)$ \\
\hline 3 months & 12 & $\left(\begin{array}{r}8 \\
67\end{array}\right)$ & 12 & $\left(\begin{array}{r}8 \\
67\end{array}\right)$ & 9 & $\left(\begin{array}{r}12 \\
134\end{array}\right)$ \\
\hline 6 months & 7 & $\left(\begin{array}{r}4 \\
55\end{array}\right)$ & 6 & $\left(\begin{array}{r}3 \\
55\end{array}\right)$ & 6 & 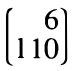 \\
\hline 1 year & 6 & {$\left[\begin{array}{r}3 \\
53\end{array}\right]$} & 6 & $\left(\begin{array}{r}3 \\
53\end{array}\right)$ & 3 & {$\left[\begin{array}{r}3 \\
106\end{array}\right)$} \\
\hline
\end{tabular}

6 months, two thirds had astigmatism with the rule (plus cylinder at $90^{\circ}$ ) while the other third had astigmatism against the rule (plus cylinder at $180^{\circ}$ ) or obliquely in equal numbers. The astigmatism that remained at 1 year was against the rule in two thirds and with the rule in one third, the $180^{\circ}$ plus cylinders persisting from $180^{\circ}$ or oblique astigmatism at 6 months. The with-the-rule astigmatism at 6 months had largely disappeared by 1 year.

Several explanations of the suspiciously frequent occurrence of infant astigmatism have been suggested including poor fixation of the infant's eyes and noncoincidence of the optical and visual axis with infants' large angle alpha. ${ }^{20}$ In our series, holding open the eyelids was not a significant factor in the aetiology of the astigmatism as the highest incidence $(42 \%)$ occurred at 6 months of age when as little forced lid opening was required as at 1 year (15\%); the most force required to open the lids was exerted in the examination at birth when the incidence of the astigmatism was at its lowest (10\%). It seems that large numbers of infants are temporarily astigmatic but do not become amblyopic. In our study we saw no amblyopia in any of the astigmats nor in the anisometropes who had no concomitant high hypermetropia. We did, however, put one child, who was under paediatric care for developmental delay, into vertical astigmatic plus 2.5 cylinders at the age of 20 months because her vision did not seem to be developing adequately.

Since high hypermetropia is extremely common in the newborn, astigmatism is equally common at 6 months of age, and since both conditions are reduced markedly at 1 year, we feel that screening by refraction before 1 year of age might be counterproductive in that it could lead to the wearing of unnecessary spectacles by large numbers of temporarily hypermetropic infants. If amblyopia is discovered at 1 year and a refractive error is then found the refractive error may then be corrected and the amblyopia may well disappear with no occlusion.

Retinoscopy can be performed by orthoptists, but it is time-consuming and all infants require cycloplegia. We feel that progress will be made when orthoptists are able to screen 1-year-olds with a reliable, quick test that can detect a difference of vision between the two eyes. Amblyopia itself will then be identifiable rather than merely its risk factors.

Key words: Amblyopia, Refraction, Retinoscopy, Screening.

\section{REFERENCES}

1. Ingram RM: Refraction as a basis for screening children for squint and amblyopia. Br J Ophthalmol 1977, 61: 8-15.

2. Ingram RM, Walker C, Wilson JM, Arnold PE, Dally S: Prediction of amblyopia and squint by means of refraction at one year. Br J Ophthalmol 1986, 70: 12-15.

3. Abrahamson SV: Bilateral ametropic amblyopia. J Pediatr Ophthalmol Strabismus 1964, 1: 57-61.

4. Mitchell D and Wilkinson F: The effect of early astigmatism on the visual resolution of gratings. J Physiol (Lond) 1974, 243: 739-56.

5. Ingram RM: Refraction of 1 year old children after atropine cycloplegia. Br J Ophthalmol 1979, 63: 343-7.

6. Atkinson J, Braddick OJ, Durden K, Watson PG, Atkinson S: Screening for refractive errors in 6-9 month infants by photorefraction. Br J Ophthalmol 1984, 68: 105-12.

7. Howland HC, Atkinson J, Braddick O, French J: Infant astigmatism measured by photorefraction. Science 1978, 202: 331-2.

8. Mohindra I, Held R, Gwiazda J, Brill S: Astigmatism in infants. Science 1978, 202: 329-30.

9. Ingram RM and Barr A: Changes in refraction between the ages of 1 and 31/2 years. Br J Ophthalmol 1979, 63: 339-42.

10. Dobson V, Fulton AB, Sebris Lawson S: Cycloplegic refractions of infants and young children: the axis of astigmatism. Invest Ophthalmol Vis Sci 1984, 25: 83-7.

11. Howland HC, Sayles N: Photorefractive measurements of astigmatism in infants and young children. Invest Ophthalmol Vis Sci 1984, 25: 93-101.

12. Gwiazda J, Scheiman M, Mohindra I, Held R: Astigmatism in children: changes in axis and amount from birth to six years. Invest Ophthalmol Vis Sci 1984, 25: 88-92.

13. Mohindra I: A technique for infant vision examination. Am J Optom Physiol Optics 1975, 52: 867-70.

14. Evans E: Refraction in children using the Rx 1 autorefractor. Br Orthop J 1984, 41: 46-52.

15. Helveston EM, Pachtman MA, Caderew W, Ellis FD, Emmerson BS, Weber J: Clinical evaluation of the Nidek AR autorefractor. J Pediatr Ophthalmol Strabismus 1984, 21: 227-30.

16. Regan D: Rapid objective refraction using evoked brain potentials. Invest Ophthalmol Vis Sci 1973, 12: 669-79.

17. Amold PE, Billingham B, McGarrigle M, Hopkisson B: Can orthoptists refract? Br Orthop J 1991, 48: 46-7.

18. Ingram RM, Arnold PE, Dally S, Lucas J: Results of a randomised trial of treating abnormal hypermetropia from the age of 6 months. Br J Ophthalmol 1990, 74: 158-9.

19. Hopkisson B, Arnold P, Billingham B, McGarrigle M, Entwhistle P: Visual assessment of infants: vernier targets for the Catford Drum. Br J Ophthalmol 1991, 75: 280-3.

20. Banks M: Infant refraction and accommodation. Int Ophthalmol Clin 1980, 205-30. 